\title{
How does a populist government interpret and face a health crisis? Evidence from the Mexican populist response to COVID-19
}

\section{Cesar Renteria 1 \\ David Arellano-Gault 1}

1 Centro de investigación y Docencia Económicas, Ciudad de México - México

In 2020, governments were faced with addressing the health crisis caused by the COVID-19 pandemic, without certainty about what would work best to reduce the health crisis without ruining the economy. Through all the uncertainty, national governments based their responses to COVID-19 on beliefs and political ideas, which was reflected on the diversity of the responses: liberal, authoritarian, centralized, decentralized, transparent, or opaque. In this article we focus on one of these responses, populism, and seek to understand how populist beliefs drive bureaucratic actions taken by a populist government to handle the health crisis. We conducted a comparative case study between the Mexican populist federal government and the non-populist Jalisco state government. Our findings suggest that the administrative actions chosen by the Mexican populist government were based on negative beliefs towards expert scientific knowledge from outside the government; a disinterest in searching for more information from distant or unfamiliar sources; and a strengthening of flagship programs as the main way to address the upcoming economic crisis. We also found that the Mexican government shows a peculiar manifestation of populism, which we refer as downsizing populism. Our article advances our understanding about how populism may affect the form and function of bureaucracies.

Keywords: COVID-19; populism; public administration; Mexico; comparative analysis.

\section{Como um governo populista interpreta e enfrenta uma crise na área de saúde? Evidências provenientes da resposta populista mexicana à COVID-19}

Em 2020, os governos foram confrontados com a necessidade de enfrentar a crise sanitária causada pela COVID-19, sem ter certeza sobre quais as melhores alternativas para lidar com a pandemia sem arruinar a economia. Em um marco de incerteza causada pelo novo vírus, os governos nacionais basearam suas respostas em crenças e ideias políticas, o que se refletiu na diversidade de respostas: liberais, autoritárias, centralizadas, descentralizadas, transparentes ou opacas. Nesse artigo, nos concentramos em um desses tipos de resposta, o populismo, e buscamos entender como as crenças populistas determinam as ações burocráticas adotadas por um governo para lidar com a crise sanitária. Com esse objetivo, fizemos um estudo de caso comparativo entre o governo federal mexicano (populista) e o governo do estado de Jalisco (não-populista). Nossos resultados sugerem que as ações administrativas adotadas pelo governo federal (populista) foram baseadas em crenças negativas com relação ao conhecimento científico especializado procedente de fora do governo; um desinteresse em buscar mais informações em fontes distantes ou pouco conhecidas; e o fortalecimento dos programas emblemáticos como a principal forma de enfrentar a crise econômica que se aproxima. Também descobrimos que o governo federal mexicano representa uma manifestação peculiar de populismo, que denominamos populismo downsizing (populismo que promove a redução do tamanho do estado). Nosso artigo permite avançar nosso entendimento sobre como o populismo pode afetar a forma e a função das burocracias.

Palavras-chave: COVID-19; populismo; administração pública; México; análise comparativa. 


\section{¿Cómo interpreta y enfrenta un gobierno populista una crisis de salud? Evidencia de la respuesta populista mexicana a la COVID-19}

En 2020, los gobiernos se enfrentaron a la necesidad de abordar la crisis de salud causada por la COVID-19, sin estar seguros de qué funcionaría mejor para abordar esta crisis de salud sin arruinar la economía. En un marco de incertidumbre provocado por el nuevo virus, los gobiernos nacionales basaron sus respuestas en creencias e ideas políticas, lo que se reflejó en la diversidad de respuestas: liberales, autoritarias, centralizadas, descentralizadas, transparentes o veladas. En este artículo, nos enfocamos en uno de esos tipos de respuestas, el populismo, y buscamos entender cómo las creencias populistas determinan las acciones burocráticas tomadas por un gobierno para enfrentar la crisis de salud. Para ello, realizamos un estudio de caso comparativo entre el gobierno federal mexicano (populista) y el gobierno del estado de Jalisco (no populista). Nuestros resultados sugieren que las acciones administrativas tomadas por el gobierno federal se basaron en creencias negativas con respecto al conocimiento científico especializado proveniente de fuera del gobierno; falta de interés en buscar más información de fuentes lejanas o poco conocidas; y el fortalecimiento de programas emblemáticos como principal forma de enfrentar la crisis económica que se avecina. También encontramos que el gobierno federal mexicano representa una manifestación peculiar del populismo, al que denominamos "populismo reductor" (populismo que promueve la reducción del tamaño del estado). Nuestro artículo nos permite avanzar en nuestra comprensión de cómo el populismo puede afectar la forma y función de las burocracias.

Palabras clave: COVID-19; populismo; administración pública; México; análisis comparativo.

\section{ACKNOWLEDGMENTS}

We thank the Editor and two anonymous referees for their suggestions. We also thank Verónica Carlos Camarena for her support collecting the data.

\section{INTRODUCTION}

The 2020 COVID-19 health crisis caught off guard most governments around the world. At the beginning of the outbreak, between January and March, governments needed to adapt their public health systems in the face of a rapidly changing environment. The health risks associated with the epidemics pressed governments to take decisions with urgency and incomplete information to avoid losing human lives.

"This is war," said the French President Emmanuel Macron about facing the epidemics crisis; and we witnessed diverse ways in which governments waged this war. When uncertainty surrounds new or unexpected circumstances, organizations tend to rely on prior beliefs and their culture to make sense of the circumstances going on (Levitt \& March, 1988; March \& Olsen, 1975). The uncertainty emerged from this novel virus brought diversity of reactions from national governments, which reflected their differences in beliefs and political ideas to make sense of what would work best to face the health crisis without ruining the economy. The responses we observed can be classified in different ways, from liberal to authoritarian, from centralized to decentralized, from transparent to opaque (Cohen \& Kupferschmidt, 2020). China, for example, banned travel from or to the province of Hubei (Kupferschmidt \& Cohen, 2020); Taiwan privileged fast actions over border control and proactive testing of suspect cases (Wang, Ng \& Brook, 2020); South Korea promoted massive testing of suspect cases (Park, Choi \& Ko, 2020); while Sweden opted for moderate measures of self-isolation and testing to gradually develop "herd immunity" (The Economist, 2020). 
Among all these reactions, we are interested in studying how populist governments faced this health crisis. Studying populism is important, not only because it has resurged as an influential political ideology worldwide (Finchelstein, 2017; Inglehart \& Norris, 2016; Mudde \& Kaltwasser, 2017), but also because it may have implications over the form and functions of bureaucracies (Bartha, Boda \& Szikra, 2020; Peters \& Pierre, 2019; Rockman, 2019). Amid all varieties of populism, we studied downsizing populism, a manifestation of populism where public servants are characterized negatively-being put in the bucket of the corrupt-and, consequently, tends to downsize the workforce, infrastructure or institutional capacities of public organizations (Arellano-Gault, 2020; Lewis, 2018).

The health crisis caused by the COVID-19 epidemics is a good setting to study how the beliefs and culture of a populist regime condition the way a government interprets an unexpected and novel health crisis and how those beliefs shape the way the government decides to deal with it. Studies about organizational learning, adaptation to changes in the environment and dynamic capabilities coincide in pointing out that an abrupt change in the environment may render routines and current knowledge or practices unfit to deal with novel circumstances, and therefore the organizations may rely on other sources to make sense of the circumstances (for example, prior beliefs or distant search) (Eisenhardt \& Martin, 2000; Huber, 1991; Levitt \& March, 1988; March, 1991).

In this article, we seek to explore the beliefs driving the bureaucratic actions taken by a populist government to handle the health crisis. To do so, we selected the case of Mexico for a comparative analysis. Since 2018, a populist leader took over as President, bringing along with him an ambitious agenda to reform the public institutions. Arguably, Mexico had time as a relative advantage, compared with other countries, to handle the COVID-19 epidemics. The first confirmed case in Mexico was found on February $28^{\text {th }}$, almost two months after the World Health Organization's (WHO) declaration of the novel coronavirus (2019-nCoV). At that moment, more and more information was being produced and being shared through communities of practice (i.e., scientists, policymakers, and journalists). Nevertheless, as of August 2020, Mexico was the $7^{\text {th }}$ country with more contagions in the world and the $3^{\text {rd }}$ with more deaths, only surpassed by two countries ran also by populist presidents: United States and Brazil (WHO, 2020) (see Table 1).

TABLE 1 COUNT CONTAGIONS AND DEATHS CAUSED BY COVID-19, BY COUNTRY (TOP 5)

\begin{tabular}{|l|c|c|}
\hline Country & Total Deaths & Total Cases \\
\hline 1.USA & 177332 & 5719841 \\
2. Brazil & 116580 & 3669995 \\
3. Mexico & 61450 & 568621 \\
4. India & 60450 & 3310234 \\
5. United Kingdom & 41465 & 328850 \\
\hline
\end{tabular}

Source: World Health Organization (2020). 
This article is divided in seven sections, including the foregoing introduction. In the second section we will lay down the conceptual background of populism, and we provide a speculative thought about the populist beliefs that may have implications on the functioning of bureaucracies. In the third section, we detail the characteristics of our case study, the Mexican populist government in office for the period 2018-2024. In the fourth section, we describe the methodology we used to analyze this case. In the fifth section, we provide our main findings, while in the sixth section we further discuss our findings and their implications in the broader literature of populism and public administration. Finally, in the seventh section, we lay down some conclusions and list some venues for future research.

\section{POPULISM, POPULIST BELIEFS, AND ADMINISTRATIVE ACTION}

Populism is defined by Mudde as "a [thin-centered] ideology that considers society to be ultimately separated into two homogenous and antagonistic camps, 'the pure people' versus 'the corrupt elite,' and which argues that politics should be the expression of the volonté générale (general will) of the people" (Mudde, 2004, p. 543). The populist rhetoric conveys ordinary people as a homogenous group where everybody is "honest," "intelligent," and "deserving" people. Ordinary people are the heroes of the tale, whom can never be wrong. On the other hand, the elite is portrayed as a deviant group, being labeled as "greedy," "arrogant," "corrupt," or "incompetent" (Inglehart \& Norris, 2016; Schneider \& Ingram, 1993). One of the main consequences of this political discourse is the polarization of society; a struggle of "us" against "them;" the "people" against the "elite," and where opposers to the regime are against the will of the "people" and therefore on the wrong side of the history.

Populism is a strange political creature; it lives in the right and left ends of the political spectrum, as different manifestations of populism comprise different set of beliefs and a varied coalition of interests (Pappas, 2016). But regardless of the wing, populism is of concern in public administration scholarship because it may have implications on the form and function of bureaucracies.

The main implications may come in the form of administrative reform. Under the populist Manichean worldview of virtue and vice, populist leaders may find in administrative reforms a means to institutionalize their ideology into the daily government operations. Administrative reforms may also become an instrument to weaken the relative independence of administration from politics, thus competence-a core value of public service-may be replaced by loyalty.

It is yet unclear, however, how populism may affect the form and function of bureaucracies (Bartha, Boda \& Szikra, 2020; Peters \& Pierre, 2019; Rockman, 2019). To better understand this, we must study their definitions of who belong to the ordinary people or to the elite, as well as the beliefs and coalitions driving their political discourse and agenda. Populist ideologies vary in their definition of who belongs to the ordinary people and the elite. It is not evident among different populist manifestations whether public servants are rhetorically positioned within the group of ordinary people or to the elite. Indeed, these two groups are vague and highly malleable through discourse. Inglehart and Norris (2016, p. 2), for example, have described a vast pool of groups and guilds that may belong into each category. The have observed that the ordinary people may be composed of "low-waged unskilled workers, long-term unemployed, households 
dependent on shrinking social benefits, residents of public housing, single-parent families, and poorer white populations living in inner city areas." The elite or establishment may be composed by "big business, big banks, multinational corporations, media pundits, elected politicians, and government officials, intellectual elites and scientific experts, and the arrogant and privileged rich.” (Inglehart \& Norris, 2016, p. 6).

Therefore, understanding the set of beliefs underpinning a populist ideology and the framing of who belongs to the elite are key to understand how populism affects bureaucracies. We know, for example, that some manifestations of populism are shaped by nationalist beliefs where migration and international trade may thread the locals or natives (Schumacher \& Van Kersbergen, 2016). We have additional insights on the instrumental use of bureaucracy to strengthen patronage (Grindle, 2012). However, these insights do not speak directly to public administration concerns; so far, the mapping of the specific populist beliefs likely to trigger administrative action over bureaucracies remains scarce and scattered.

We seek to contribute on this understanding by taking an organizational angle to observe how a populist government manages a health crisis. As populist governments tend to be tribal and myope towards the information, happenings, and political forces in their surroundings, we use borrowed some insights from March's (1991) exploitation/exploration to observe how a populist government dealt with the abrupt change in the environment that COVID-19 represented. Exploitation convey tendencies to look inside the organization for solutions to face organizational problems, whereas exploration convey a tendency to look for solutions outwards (March, 1991). Based on this understanding, we specifically sought to observe who did the populist government trust, what kind of information they used, how did they make sense of the changing circumstances, and what roles were assigned to the administrative elite and the ordinary people.

\section{MEXICAN POPULIST REGIME (2018-2024)}

The 2018 general elections in Mexico saw the political leader Lopez Obrador elected as President for the 2018-2024 term, and his party, Morena, won the majority in both chambers of the Congress and won several governorships. This block of newly elected politicians would brand themselves and their dawning regime as "the Fourth Transformation of the Republic" (usually referred simply as Fourth Transformation or 4T), which has been explained by Lopez Obrador as a historic revolutionary movement to eradicate corruption, inequality and insecurity (Hanrahan \& Fugellie, 2019)

We classified Lopez Obrador's regime as populist because we observed all four minimal attributes of a populist government suggested by Pappas (2016): (1) Lopez Obrador and his political group claim to represent the political demands of the majority of Mexicans; (2) this majority is portrayed as a homogeneous group (usually referred as la gente or el pueblo-i.e., "the people"), which according to the populist rhetoric have been historically undermined and exploited by the elite; (3) the populist government, through their rhetoric, distinguishes, antagonizes, and polarizes two main groups in the public life: the people and the elite; (4) members of Morena perceive themselves and their allegiances as the only ones beholding the moral right to govern. 
Lopez Obrador's regime is a left-wing populism paying no attention to migration or global trade as thread. Instead, the main themes in Lopez Obrador's rhetoric revolve around social justice, fight against corruption, and a republican austerity. Austerity is perhaps the main value of this regime shaping the form and function of the Mexican bureaucracy, as it conveys a belief that every public servant has a moral obligation to abide to austerity in their public and private life.

Regarding the framing of the elite, Lopez Obrador's definition of the groups and guilds belonging to the elites is somehow scattered, without any family resemblance pattern. However, we have observed in his rhetoric negative portrayals of businesspeople, scientists, journalists, artists, critics, political adversaries, and-crucially for this study-public servants. For example, this regimes has regime denigrated in its discourse public servants as the "golden bureaucracy," framing them not as lazy or incompetent as in other populist manifestations (Peters \& Pierre, 2019), but as intellectually arrogant, socially insensitive, lavish, and corrupt (Proceso, 2020; Sanchez, 2019).

Compared with other manifestations of populism, Lopez Obrador's populism is distinctive by combining a portrayal on public servants as part of the elite and a belief in austerity as a purifying mechanism of the public service ethos. These combined beliefs have already triggered administrative reforms aiming to downsize to government. This agenda of administrative reform has been instrumented, so far, through substantial budget cuts; a great amount of employees fired; public servants' salaries, social security and other labor rights have been neglected or reduced; and unilateral shutdowns-through executive orders—of widely studied and reputed Federal programs (e.g., conditional cash transfer programs), regulatory agencies and public institutions (Molina, 2020; Pinon \& Diaz, 2020; Urrutia \& Jimenez, 2020). The President's relationship with public servants has been tense at several moments. The silent expectative of public servant's loyalty to their political leaders instead of professionalism and competence can be felt in the firing of several public servant-even those protected by the professional civil service-and the resignation of 14 top decision-makers (Ministers and Deputy Ministers) within a year of government (Hernandez, 2019). The President's distrust in public servants has also been manifested by the use of military for policing (Mosso, 2020) and a variety other government duties, such as building airports and railroad systems, managing customs, or reforestation (Ortiz \& Espino, 2020).

We named this peculiar manifestation of populism as downsizing populism, which is characterized, primarily, because it includes public servants (and technocrats) into the elite. The rhetoric of Lopez Obrador's downsizing populism revolves around three main beliefs about public service. First, that bureaucracy has been captured by interest groups, and therefore has become merely an apparatus serving the elite and entrenched interests. Second, that as a consequence, public organizations are not effective, nor efficient, in many cases, not even necessary. Lopez Obrador often regards the size, structure and functions of public organizations as sumptuous institutions born out of the of the administrative elite's greed.

Third, Lopez Obrador's rhetoric also portrays public servants as an administrative elite that has become excessively technocratic and unconcerned with the people's "true" needs (Arellano-Gault, 2020). Under this belief, technical expertise is deemed as overrated and unnecessary. Instead, public problems are considered not as intricate and complex as experts say. Under this view, satisfying the 
needs and demands of ordinary people does not require complex solutions: political will, common sense, and a halo of honesty account for the best solution to address deep social problems (ArellanoGault, 2020). Optimists may argue that this characterization may help to sanitize public institutions by expelling underperforming employees, while pessimists may expect the opposite: the deterioration of organizational capacities to deliver public services and, consequently, a decreased organizational performance.

The Mexican populist regime entered the emerging COVID-19 health crisis with a weakened health public system and a society drawn into the polarization of the ordinary people/elite antagonism. In fact, the Federal government was in the course of cancelling the Seguro Popular, the biggest social security system in the country (covering, approximately, half of the economically active population). Despite the pandemics, the Seguro Popular was officially terminated.

In the Mexican Federal system, states are responsible for running the public health systems (i.e. building and maintaining infrastructure and affording the payroll), whereas the Federation are responsible for managing the three social security systems (IMSS, ISSSTE and Seguro Popular) and-among other national policies - the National System of Epidemic Monitoring (Flamand \& Jaimes, 2015). These institutional arrangements set a classic problem of governance, where financial, administrative and technical autonomy are interweaved with the interdependence need to effectively handle the COVID-19 health crisis.

Despite these institutional conditions and the pressing need for coordination, the political stances between Lopez Obrador's government and governors from opposing parties were polarized. This political strategy has created a basic ambience in the political arena: polarization. Nowadays in Mexico, in newspapers, political debate, and all other types of discussion, the society has been divided into two parts: wealthy against poor; conservative against the people, elites (mocked by the President as "fifís," a pejorative term for rich people) against "chairos" (a pejorative term used to refer to all uneducated people). These terms have been used even to frame argumentations in policymaking.

Under these circumstances, the coordination of a public health strategy to face COVID-19 showed several cracks in several dimensions: discourse, strategy, and policy. To face the COVID-19, Governors from opposing parties followed different rhetoric and strategies than the followed by the Federal government. These differentiations began to crack a much needed national strategy and, consequently, fueled the ongoing political polarization between Governors and the Federation as well as the social polarization. Then, slowly, the administrative tensions revolving collaboration to face the COVID-19 crisis moved towards the realm of political battles among political groups and among a polarized society; strategies, coordination, information release, all of them critical issues to face the problem of the pandemic, were entrapped in the political situation. Besides the weakening of the public sector, these political battles and cracks in national coordination cemented an environment of lack of trust among the different levels of government. This is the political context that shed light to interpret the analysis that follows. 


\section{METHODOLOGY}

To analyze the case of Mexican populist Federal government in office for the period 2018-2024, we did a comparative case study. We compared the Mexican Federal government and the Jalisco State, whose governor Enrique Alfaro (also elected for the period 2018-2024) is a pragmatic and non-populist ${ }^{1}$ politician belonging to an opposing political party to Morena. This comparison may seem inappropriate over a first look, because Jalisco state is a political sub-unit of the Federation and thus not a completely independent case. However, the Mexican Federal system (as described in the previous section) provides strong attributions to the states, especially in health and education policy. Most importantly, for the specific study of government reactions to the COVID-19 a case comparison among countries may be difficult, as the key variables confounding variables influencing the way governments reacted vary considerably. For example, the information and knowledge about the virus at the time of the first case diagnosed with COVID-19, the administrative capacitates and infrastructure (e.g. hospitals, nurses, and doctors per 100 inhabitants) to face the crisis, the state of the economy, the cultural, political and institutional backgrounds all are likely to be very different among countries. The comparison between the Federal and the Jalisco state governments, therefore, ensures that all these variables are kept constant, which strengthens the most-similar case selection strategy (George \& Bennett, 2005). Therefore, these cases are similar in the dependent variable: undertaking government actions to face the same health crisis during the same period, and relatively same access to information about the nature of the virus and how other countries have faced the contagion. The cases are different in the independent variable, however, which is the whether the government shows a populist ideology or not; in turn, this variation may be the source to observe further variation in the beliefs and standpoints about how to face the health crisis.

Our main goal making an initial effort to explore whether there are differences beliefs between the populist and non-populist case that may influence the government response (e.g. beliefs about the role of ordinary people and elites, and the information trusted and used for decision-making). Therefore, our approach is primarily inductive, seeking to uncover patterns in our data that may suggest differences in beliefs.

Our data collection and data analysis followed two stages. In the first stage, we collected data on official communication form the Federal Ministry of Health (bulletins, press releases, reports, etc.) to identify the key information regarding the awareness from Federal authorities about the evolution of the pandemics worldwide since January $11^{\text {th }}$ as well as to understand the evolution of epidemics in Mexico. This initial data was composed by 53 sources. In the second stage, we sought to interpret the standpoints or actions for each case through their narratives. We understand standpoints as the attitude towards an issue or the worldview describing or

\footnotetext{
${ }^{1}$ Our classification of Alfaro as a non-populist governor is based on reviews of his political background and political ideology (GomezAlvarez, 2018), where did not find evidence of the four attributes suggested by Pappas (2016). But Alfaro's non-populism (or pragmatism) can also be observed in the recurring and well documented ideological clashes between Alfaro and Lopez Obrador (El Informador, 2019), and the fact that Alfaro has been member of three different political parties and he ran for elections, on several occasions, as an independent candidate.
} 
explaining the actions undertaken. Once the standpoints were identified for different issues, we identified the beliefs supporting the standpoints. To do so, we collected data (i.e. public addresses, interviews or institutional bulletins) from Andres Manual Lopez Obrador (Mexican President) and Hugo Lopez-Gatell (Vice-Minister of Public Health and appointed spokesperson for the COVID-19 crisis management) to account for the Federal standpoint, and from Enrique Alfaro Ramírez (governor) and Fernando Petersen (State Ministry of Health) to account for the Jalisco standpoint. In the second stage, our final data was composed by 47 from a variety of sources (e.g., press articles, interviews, press releases, transcripts of discourses, etc.), from which we bounded the text to 159 extracts directly related with the management of the health crisis. From this data, we generated 18 open codes, which later were into a smaller number of topics convey the backbone of this analysis (for example, calmness, urgency, trust other's evidence, and inherent strength). The complete listing of the sources and its systematization can be found in the online supplementary information.

\section{COMPARING POLICY STANDPOINTS AND BELIEFS}

We identified contrasting standpoints in three key issues with regards to populism in public administration: (1) finding the best course of action to face the crisis, (2) defining policies to safeguard the economy, and (3) the governments' expectations from citizens to face the crisis. Below, we will discuss the differences in these three issues.

Finding the best course of action to face the crisis. Both entities reacted with relative speed to the incoming crisis. After the WHO publicly recognized the novel coronavirus (2019-nCoV) on January $10^{\text {th }}$, the Mexican Federal government prepared and issued a contingency plan on January $30^{\text {th }}$. The Plan pre-defined in three Phases the actions to be taken; the Phases were defined by a list of milestones to be met. Despite the lack of prior knowledge about the features and behavior of the SARS-CoV-2 virus, and the drastic change of the environment worldwide in the weeks to follow, the Federal government always kept an unwavering adherence to their initial Plan.

On the other hand, the government of Jalisco initially followed the Federal Plan, but once the WHO declared the pandemics on March $11^{\text {th }}$, the State defined its own trajectory. The governor of Jalisco decided to react fast with measures being implemented in other countries and instilled a sense of urgency and decisiveness in its narrative. This sense of urgency contrasted with the sense of calmness conveyed by the Federal government, not only through discourses, but also in the way and timing policies were implemented (See Figure 1). 


\section{FIGURE $1 \quad$ COMPARISON OF CONTAGION CURVES AND POLICY MILESTONES BETWEEN FEDERAL AND JALISCO GOVERNMENTS}
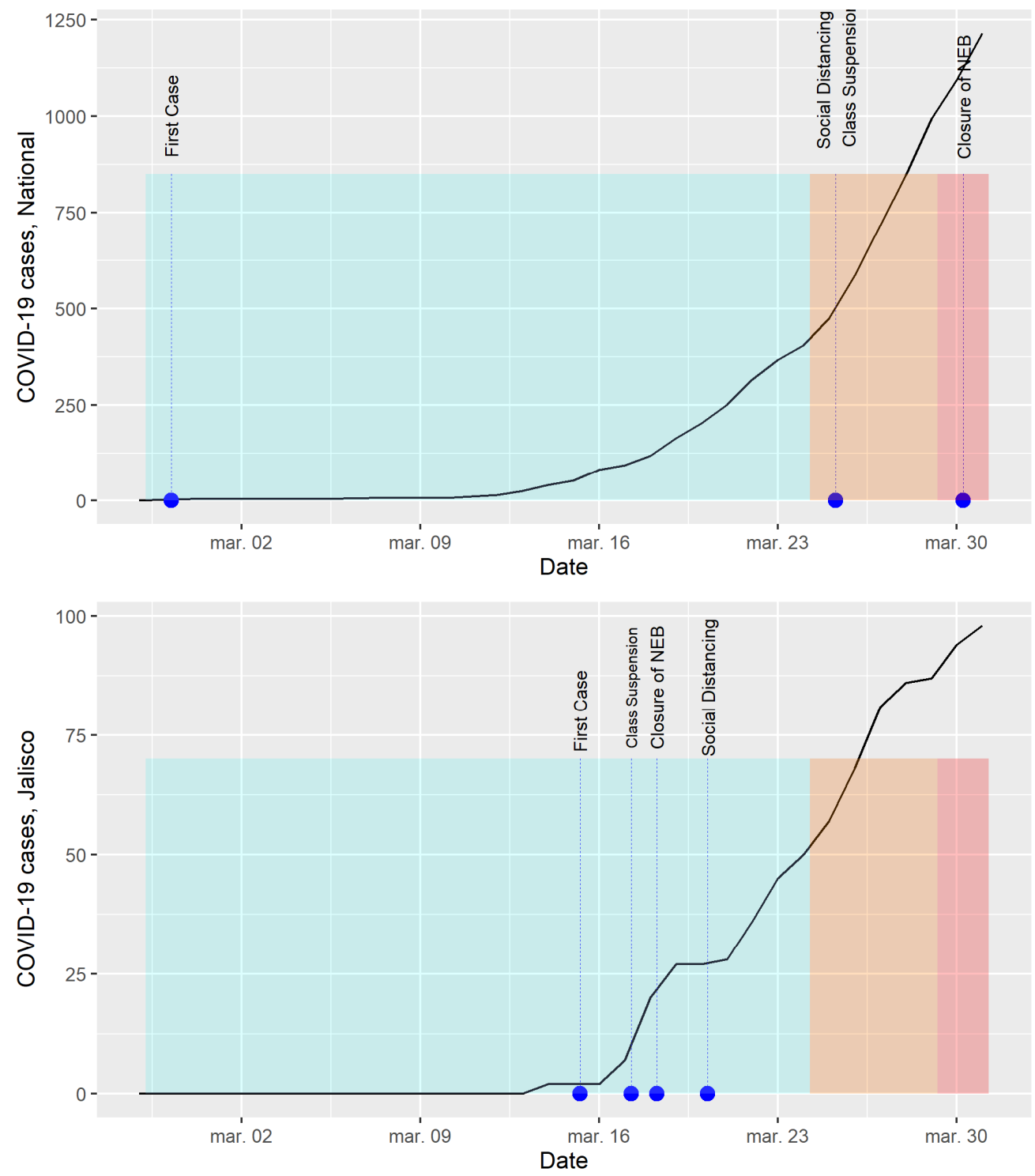

Notes: The upper panel displays data of confirmed diagnoses at the national level. The lower panel displays data of confirmed diagnoses only from Jalisco. NEB stands for non-essential businesses.

Source: Elaborated by the authors.

We argue that the difference of standpoints about the best course of action to face the crisis is explained by differences in beliefs. On the one hand, the Federal government believed, above all else, in the expertise and proficiency of its own experts. On several occasions, the President paid deference to the experts, while Lopez-Gatell-the chief expert, so to speak-was highly disdain of knowledge and policies sourced from experts outside the Federal government. For example, Lopez-Gatell, at an early stage, manifested against the controlling international traffic, imposing social distancing, closing 
non-essential businesses, massive testing, and even the use of masks; dismissing them as actions based on "panic" and "fear," or "unscientific" solutions. The Federal government, for example, was reluctant to conduct massive tests, under the argument that these are useless and expensive. At an early stage, the use of masks in the streets was optional and, at some moments Lopez-Gatell deemed them as unnecessary or ineffective. Lately, the Federal government strategy evolved towards the control of information and the forecasting of a mathematical model.

We consider that the standpoint taken by the Federal government was grounded in a self-confidence cemented by past positive experiences. In 2009, Mexico successfully handled the H1N1 epidemics crisis, where Lopez-Gatell was a key member of the crisis management team. This experience also reinforced the trust in procedures-such as the Plan-because after this experience the Federal government developed institutional capabilities for preparedness a Centinel System, which were the foundation of the 2020 response Plan. Federal government trusted its own experience and procedures as mechanisms to face the uncertainty of this novel thread. This is consistent with the logics of appropriateness, where organizations learn by trial and error-dismissing failed solutions and retaining successful ones (Levitt \& March, 1988). We consider that these beliefs shaped the sense of calmness observed from the Federal government.

Jalisco's main standpoint about the best course of action was acting on a logics of consequentiality; this is, seeking to form a mental model about the world linking actions with their expected consequences (Levitt \& March, 1988). Before adopting a strategy, the approach from the government was searching for relevant and trustable knowledge about policy actions and their expected consequences. Jalisco's standpoint was motivated by recognizing the uncertainty and novelty inherent to the COVID-19 health crisis and was grounded in a strong belief that the emergent knowledge about the virus and the policies to contain it were founded in strong empirical evidence or valuable experts, so that they provided certainty about how and why some actions will render positive outcomes. Therefore, their best course of action was following experts' recommendations and actions proving to be successful in other countries. We consider that the towering figure of the WHO as a source of expert advice along with ongoing seemingly effective policies being implemented around the world explain the sense of urgency observed in this case.

Safeguarding the economy. Measures of social distancing conflicted with the normal running of the economy, and all governments were faced to find the least harmful solutions to safeguard the public health, while preventing a major economic collapse. In this regard, Jalisco reacted fast and decisively, being the first entity in Mexico to suspend in-place classes, social distancing, and the closure of non-essential businesses. Jalisco government quickly announced an economic recovery plan aimed at protecting workers in vulnerable employments. We did not find information about how the economic package would be financed. The Federal government also emphasized the goal of protecting workers in vulnerable employments but was hesitant during the first stage to close non-essential business. The Federal government approach to safeguard the economy, at an early stage, was to keep running the economy and increasing the budget of two Federal flagship cash transfer programs: Adulto Mayor (Support to Elders) and Programa Integral de Bienestar (Integral Program for Welfare).

Interaction with citizens. The governor of Jalisco addressed his constituents several times to ask their cooperation with strict social distancing measures. He used discourse as an instrument 
of persuasion to instill a sense of civic responsibility among citizens. We argue that the core belief driving this standpoint was that citizens were the main responsibility of the success or failure of the contention strategy.

In contrast, the discourse of the Federal government did not ask citizens for any role to play in their contention strategy. We argue that core belief of Federal government with regards to citizens was that ordinary people had an inherent ability to overcome adversity, and therefore the citizens were apt enough to overcome the risk of contagion or the foreseeable economic difficulties. The Mexican president used discourse as an occasion to emphasize such qualities of people by stating, for example, that "Mexicans are used to face adversity," "we must have faith in our people," "where is our strength? In our people and culture." The Table 2 summarizes the main differences among the Federal and Jalisco state governments regarding these three dimensions.

\section{TABLE 2 SUMMARY OF COMPARATIVE STANDPOINTS}

\begin{tabular}{lcc} 
& \multicolumn{2}{c}{ Ideology } \\
\hline $\begin{array}{l}\text { Pogics of action } \\
\text { Knowledge trusted }\end{array}$ & Appropriateness & Non-populist \\
Own experts & Consequentiality \\
Economic recovery & WHO experts and other countries' \\
Role of citizens & reactions \\
\hline
\end{tabular}

Source: Elaborated by the authors.

\section{DISCUSSION AND IMPLICATIONS}

The difference in beliefs did led to the two compared governments to take different actions to face the health crisis. The populist government only valued the knowledge and information from their own experts, while disdaining insights from other sources. For example, Lopez-Gatell labeled some proposed solutions (including the use of masks) as "unscientific." The populist regime used a logic of appropriateness as a mode of action under uncertainty; this means making sense of the circumstances based on their prior beliefs and somehow related previous experiences in crisis management. We did not find positionings regarding the role of administrative elites, nor downsizing the government as part of their sensemaking of the problem and their solutions. However, we observed that ordinary people were framed in this health crisis as a passive entity whom inherent strength and tenacity to face adversity would suffice to overcome the health risks. This believe may have contributed to the perceived slow and relatively innocuous initial response from the Federal government to minimize contagion; the populist government chose not to use carrots, nor sticks, nor sermons to influence citizens' behavior. Finally, we observed that, for Federal government, actions to revitalize the economy were closely associated with their flagship programs. For example, an early response to the crisis was 
to increase the budged of two cash transfer programs and to resume the construction of a flagship railroad. We found in our data a pattern suggesting that, to some extent, the health crisis brought an opportunity for the Federal government to reassure its compromise against corruption and in favor of the vulnerable economic trades, which would be materialized through direct cash transfers.

In contrast, the non-populist Jalisco state government based their understanding of the circumstances based on external expert knowledge, making several references to recommendations from the World Health Organization's experts and to the experiences of countries that addressed their epidemics at an early stage (e.g. China, South Korea, Taiwan, and Japan). These insights suggest that the non-populist government reacted based on a logic of consequentiality, where important efforts were put in scanning the environment in search for policies and administrative actions, as well as data and causal explanations that, even if incomplete or inaccurate, as the events and information evolved, these would help the government to make sense of the circumstances. Although we were not able to validate in our data a consistent positioning over the role of administrative elites, the fact that governor emphasized several times the importance of experts in making decisions either at the Federal level and at the state level is a weak suggestion of a positive framing of public servants. The role of the ordinary people framed by the governor was contrasting with that of the President. In the governor's rhetoric, citizens were urged to take responsibility several times, up to the extreme of the governor once using profanity or offensive language to label and blame as "irresponsible" to people not following the preventive instructions. Finally, the governor's rhetoric with respect to the economy was dual. On the one side, the governor of Jalisco emphasized several times his awareness of committing unpopular economic actions in pursuit of safeguarding the public health. On the other hand, his government developed an economic recovery plan tailored to address the most weakened trades and jobs by the health crisis.

Regarding the implications of populism over public administration, we addressed this topic from a very specific angle; we observed the populist beliefs shaping the strategies to handle a health crisis characterized by uncertainty and an urgent need of government adaptation to the new circumstances. We found that the populist was slow to adopt any strategy to face the crisis and, once selected, the strategies showed signs of misfit to adequately address to the changing circumstances. The populist government did little to none scanning for emergent information to inform their policy choices. Instead, the populist government chose to reinforce prior beliefs and prior agendas of political and administrative reforms. We also observed that Lopez Obrador's framing of the policy solutions were, at an early stage of the crisis, associated with strategies to strengthen patronage, such as promoting a passive role of citizens, and increasing the funding of flagship programs associated with cash transfers and building infrastructure (Oliveros, 2016).

In contrast, the non-populist government was quick to inform and update their policy choices on the rapidly evolving information, not only from near and familiar sources (i.e. WHO, or countries with cultural and institutional affinity), but also from distant sources (i.e. policies being implemented in Asian countries). This comparison contributes to understand the idiosyncrasy of downsizing populism with regards to adaptation and response capacity to crisis. In sum, we found a negative association of downsizing populism with factors that are expected to improve the performance of organizations under uncertainty and changing scenarios (Eisenhardt \& Martin, 2000; Levitt \& March, 1988; March, 1991; 
March \& Olsen, 1975). For example, we observed a negative association with scanning for valuable-yet incomplete and inaccurate-information, with the search for information from unfamiliar sources, with the valuation of scientific knowledge coming from outside; but a positive association with the exploitation of previous beliefs and agendas. The disregard for scientific knowledge has been a common feature in other manifestations of populism (Finchelstein, 2017; Lewis, 2018).

This observed populist's misfit strategies and failure to address uncertainty and adapt to new circumstances is consistent with the data over CIVD-19 confirmed cases and deaths. As of August 2020, the populist of the populist governments ${ }^{2}$ of Donald Trump (United States), Jair Bolsonar (Brazil), Lopez Obrador (Mexico), and Boris Johnson (United Kingdom) top the charts on COVID-19 confirmed cases and deaths (as shown in the Table 1). In the Americas, three populist governments (Brazil, Mexico, and United States) share several similarities: these populist leaders have minimized the risks associated with the pandemics, have polarized the political discussion about public health policies, have criticized and stigmatized minorities and vulnerable groups, have engaged in conflict with other government institutions (i.e., states and legislative), and have underrated the merit of public service. The populist beliefs and the political environment promoted by populist governments may also contribute to understand how such these populist regimes and their reforming agendas may fare under the public opinion once the COVID-19 health crisis recedes.

Finally, the national management of the health crisis was a major source of political tension among the stakeholders. Overall, the political tension and the coordination deadlocks between the Federal governments and the states spiraled down during the crisis. As time passed, more states began to speak out against the Federal perceived inaction and ineffective policy choices. In May, for example, the States refused to implement the national policy proposal of adopting a traffic light to resume non-essential economic activity. This policy, governors argued, was not explained or at least consulted with them in methodological or informational terms.

\section{CONCLUSION}

This article is an inductive and exploratory study about the implications of populism on bureaucracies. Our findings were based on one particular instance of populism, which we named downsizing populism, facing the COVID-19 health crisis under conditions of uncertainty. Our main findings suggest that the administrative actions and policies chosen by the Mexican populist government were based on negative beliefs and attitudes towards expert scientific knowledge coming outside the government; a disinterest in searching for more information from distant or unfamiliar sources; a promotion of the supposed inherent strengths and ability to overcome adversity of the group framed as ordinary people; as a way to face the health crisis; and a strengthening of flagship programs as the main mechanisms to face the upcoming economic crisis.

We also observed that our case study, the Mexican populist government led by the President Lopez Obrador, is a peculiar manifestation of populism: downsizing populism. This manifestation is distinctive

2 To revise our classification of these administrations as populist, $c f r$. Finchelstein (2017, p. 41). 
because it negatively frames public servants and, therefore, places them into the rhetorical antagonist group of the elite. Along with the value of austerity adopted by this government, these two factors triggered a populist administrative reform aiming to downsize government in several aspects: size, salaries, infrastructure, and the overall number of public organizations comprising to government. As a consequence, shifts the values of public service, moving from expectations of professionalism and competence towards loyalty to leaderships. We believe that downsizing populism, compared with other types of populism, has greater implications on the public sector, and therefore it has merits on its own as subject of further studies.

Although we focused primarily on the causes of populist administrative actions, we cannot overlook the fact that the overall polarization of the political and social environment that comes along with populist rhetoric, has a strong effect on coordination. Overall, the Mexican populist government received the epidemics after reforms that weakened public institutions, which limited the capacities to handle the crisis. Also, the actions of the Federal government to face the crisis were somehow late, slow and dubitative, which contrasts with the quick and determined polarizing discursive confrontations with the administrations from opposing parties and critics. As a result, diverse state governors opposed, criticized and failed to cooperate with the Federal crisis management strategy. Ultimately, the cracks in coordination among different levels of coordination caused by populist governments will be critical to assess, in years to come, the reaction and the consequences of some populist governments undertook to face the COVID-19 health crisis.

Populist governments as said to increase the political turmoil, to weaken the democratic institutions, countervail the checks and balances systems, and to erode pluralism. However, we shall not overlook that they may also be democratically elected as a consequence of ongoing political crisis. Added to this, the way Mexican authorities faced the COVID-19 health crisis is a rich case for analysis about the political conditions that populist governments create: a political environment highly polarized, and public organizations severely downsized and undermined. 


\section{REFERENCES}

Arellano-Gault, D. (2020). Responding to the populist attack on public administration. Asia Pacific Journal of Public Administration, 42(1), 6-8.

Bartha, A., Boda, Z., \& Szikra, D. (2020). When populist leaders govern: Conceptualising populism in policy making. Politics and Governance, 8(3), 71-81.

Cohen, J., \& Kupferschmidt, K. (2020). Countries test tactics in 'war' against COVID-19. Science, 367(6484), 1287-1288.

Eisenhardt, K. M., \& Martin, J. A. (2000). Dynamic capabilities: what are they? Strategic management journal, 21(10-11), 1105-1121.

El Informador. (2019, January 23). El recuento de los choques entre Alfaro y López Obrador. Retrieved from https://www.informador.mx/Elrecuento-de-los-choques-entre-Alfaro-y-LopezObrador-t201901220003.html

Finchelstein, F. (2017). Del fascismo al populismo en la historia. Mexico, DC: Taurus.

Flamand, L., \& Jaimes, C. M. (2015). Seguro Popular y Federalismo en México: Un análisis de política pública. Mexico, DC: CIDE.

George, A. L., Bennett, A., Lynn-Jones, S. M., \& Miller, S. E. (2005). Case studies and theory development in the social sciences. Cambridge, MA: MIT Press.

Gomez-Alvarez, D. (2018, September 01). Retrato del alfarismo. Nexos. Retrieved from https://www. nexos.com. $\mathrm{mx} /$ ? $\mathrm{p}=39143$

Grindle, M. S. (2012). Jobs for the Boys. Cambridge, MA: Harvard University Press.

Hanrahan, B., \& Aroch Fugellie, P. (2019). Reflections on the Transformation in Mexico. Journal of Latin American Cultural Studies, 28(1), 113-137.

Hernandez, S. (2019, June). 14 funcionarios han renunciado durante el gobierno de AMLO. El Universal.

Huber, G. P. (1991). Organizational learning: The contributing processes and the literatures. Organization science, 2(1), 88-115.

Inglehart, R. F., \& Norris, P. (2016). Trump, Brexit, and the rise of populism: Economic have-nots and cultural backlash (HKS Working Paper No. RWP16026). Cambridge, MA: Harvard Kennedy School.

Kupferschmidt, K., \& Cohen, J. (2020). Can China's COVID-19 strategy work elsewhere? Science, 367(6482), 1061-1062.

Levitt, B., \& March, J. G. (1988). Organizational learning. Annual review of sociology, 14(1), 319-338.

Lewis, M. (2018). The fifth risk. New York, NY: Norton \& Company.

March, J. G. (1991). Exploration and exploitation in organizational learning. Organization science, 2(1), 71-87.

March, J. G., \& Olsen, J. P. (1975). The uncertainty of the past: Organizational learning under ambiguity. European journal of political research, 3(2), $147-171$

Molina, H. (2020, June 11). AMLO avala la desaparición de órganos reguladores por austeridad. El Economista. Retrieved from https://www. eleconomista.com.mx/politica/Avala-AMLOdesaparicion-de-organos-reguladores-porausteridad-20200611-0042.html

Mosso, R. (2020, May 12). Fuerzas armadas, a labor policiaca por cinco años. Milenio. Retrieved from https://www.milenio.com/policia/amlo-fuerzasarmadas-labor-policiaca-anos

Mudde, C. (2004). The populist zeitgeist. Government and opposition, 39(4), 541-563.

Mudde, C., \& C. Kaltwasser. (2017). Populism: A very short introduction. Oxford, UK: Oxford University Press.

Oliveros, V. (2016). Making it personal: Clientelism, favors, and the personalization of public administration in Argentina. Comparative Politics, 48(3), 373-391.

Ortiz, A., \& Espino, M. (2020, July 25). AMLO da 13 tareas civiles a militares. El Universal. Retrieved from https://www.eluniversal.com.mx/nacion/amloda-13-tareas-civiles-militares

Pappas, T. S. (2016). Modern populism: Research advances, conceptual and methodological pitfalls, and the minimal definition. In Thompson, W. R. (Ed.), Oxford research encyclopedia of politics. Oxford, UK: Oxford University Press. 
Park, S., Choi, G. J., \& Ko, H. (2020). Information Technology-Based Tracing Strategy in Response to COVID-19 in South Korea-Privacy Controversies. JAMA, 323(21), 2129-2130.

Peters, B. G., \& Pierre, J. (2019). Populism and public administration: Confronting the administrative state. Administration \& Society, 51(10), 1521-1545.

Pinon, A. \& Diaz, A. (2020, April 04). AMLO extingue hasta 100 fideicomisos de cultura y ciencia. El Universal. Retrieved from https://www. eluniversal.com.mx/cultura/amlo-extingue-hasta100-fideicomisos-de-cultura- $y$-ciencia

Proceso. (2019, November 23). Burocracia dorada va para afuera, dice AMLO a funcionarios del INE. Retrieved from https://www.proceso.com.mx/ nacional/2019/11/23/burocracia-dorada-va-paraafuera-dice-amlo-funcionarios-del-ine-234772.html

Rockman, B. A. (2019). Bureaucracy between populism and technocracy. Administration \& Society, 51(10), 1546-1575.

Sanchez, E. (2019, July 09). Seguirá la limpia entre la burocracia: Andrés Manuel López Obrador. Excelsior. Retrieved from https://www.excelsior.com. $\mathrm{mx} /$ nacional/seguira-la-limpia-entre-la-burocraciaandres-manuel-lopez-obrador/1323349
Schneider, A., \& Ingram, H. (1993). Social construction of target populations: Implications for politics and policy. American political science review, 87(2), 334-347.

Schumacher, G., \& Van Kersbergen, K. (2016). Do mainstream parties adapt to the welfare chauvinism of populist parties? Party Politics, 22(3), 300-312.

The Economist. (2020, May 16). Is Sweden's approach to covid-19 wise or reckless? Retrieved from https://www.economist.com/europe/2020/05/16/ is-swedens-approach-to-covid-19-wise-or-reckless

Urrutia, A., \& Jimenez, N. (2020, June 22). Se revisarán excesos en presupuestos y organismos autónomos: AMLO. La Jornada. Retrieved from https://www. jornada.com.mx/ultimas/politica/2020/06/22/serevisaran-excesos-en-presupuestos-y-organismosautonomos-amlo-4893.html

Wang, C. J., Ng, C. Y., \& Brook, R. H. (2020). Response to COVID-19 in Taiwan: big data analytics, new technology, and proactive testing. Jama, 323(14), 1341-1342.

World Health Organization. (2020, August 27). Coronavirus diseases (COVID-19) pandemic. Retrieved from https://www.who.int/emergencies/ diseases/novel-coronavirus-2019

\section{Cesar Renteria}

https://orcid.org/0000-0002-6125-5723

Invited Professor at Centro de Investigación y Docencia Económicas (CIDE). E-mail: crenteria@albany.edu

\section{David Arellano-Gault}

https://orcid.org/0000-0002-1156-3568

Professor at the Public Administration Division at Centro de Investigación y Docencia Económicas (CIDE). E-mail: david.arellano@cide.edu 